\title{
Paradigms Lost: The Blurring of the Criminal and Civil Law Models-And What Can Be Done
}

\section{About It}

\author{
John C. Coffee, Jr.†
}

Ken Mann's professed goal is to "shrink" the criminal law. ${ }^{1}$ To realize this worthy end, he advocates punitive civil sanctions that would largely parallel criminal sanctions, thereby reducing the need to use criminal law in order to achieve punitive purposes. ${ }^{2}$ I agree (heartily) with the end he seeks and even more with his general precept that "the criminal law should be reserved for the most damaging wrongs and the most culpable defendants." 3 But I believe that the means he proposes would be counterproductive-and would probably expand, rather than contract, the operative scope of the criminal law as an engine of regulation and social control.

The differences in our analyses follow from differences in our perspectives. Professor Mann's focus is largely doctrinal and basically centers on the question of whether courts will accept candidly punitive civil penalties. My perspective is more behavioral and focuses on incentives: what would regulators and private enforcers do under a legal system that largely overlaid punitive civil sanctions on top of criminal penalties? We also begin from different starting points. Although we both agree that the line between civil and criminal penalties is rapidly collapsing, Professor Mann sees (and favors) the encroachment of the civil law upon the criminal law. I see more of the reverse trend: the encroachment of the criminal law into areas previously thought to be civil or "regulatory" in character. Thus, I want to resist encroachment, while he wishes to encourage it in order to give enforcement authorities the less drastic remedy of civil penalties.

Apparently, Professor Mann sees no fundamental difference in the purposes of the civil law and the criminal law: both seek, he argues, to deter through punishment. Here, I think his usually acute powers of analysis have proven

$\dagger$ Adolf A. Berle Professor, Columbia Law School.

1. Kenneth Mann, Punitive Civil Sanctions: The Middleground Between Criminal and Civil Law, 101 YALE L.J. 1795, 1802 (1992). ("Thus, I advocate the shrinking of the criminal law in order to fit it into its proper role in the law of sanctions, next to an expanding arena of punitive civil sanctions.").

2. Id.

3. Id. at 1861 . 
myopic. Although both bodies of law seek to deter, they have historically enforced substantively different types of norms, which are purposely articulated with different levels of precision. When the criminal law is used to enforce civil law norms that are aspirational in character and deliberately soft-edged, the result may distort the civil law. More theoretical attempts to explain the civil/criminal distinction have suggested that society may have particular "transaction structures" for dealing with different areas of social behavior, sometimes using rules that trigger only civil liability and sometimes using criminal sanctions. ${ }^{4}$ Obviously, to the extent that these different "transaction structures" exist, authorizing the interchangeable use of civil or criminal sanctions may distort them. For example, applying the civil law to behavior that has traditionally been punished criminally might deprive society of its ability to focus censure and assign blame with the moral force that the criminal law may uniquely possess. In short, even if the civil law could provide equivalent deterrence, it may not be able to perform as successfully the socializing and educative roles that the criminal law performs in our society.

Professor Mann's casual use of the term "deterrence" is also somewhat imprecise. The law can deter in different ways and to different degrees. Borrowing terms coined by Professor Robert Cooter, I would suggest that in its characteristic operation, the civil law "prices," while the criminal law "sanctions." The difference between a price and a sanction is at bottom the difference between, on one hand, a tax that brings private and public costs into balance by forcing the actor to internalize costs that the actor's conduct imposes on others and, on the other, a significantly discontinuous increase in the expected cost of the behavior that is intended to dissuade the actor from engaging in the activity at all. ${ }^{6}$ From this starting point, I would argue that the criminal law should be reserved to prohibiting conduct that society believes lacks any social utility, while civil penalties should be used to deter (or "price") many forms of misbehavior (for example, negligence) where the regulated activity has positive social utility but is imposing externalities on others. This

4. See Jules L. Coleman, Crime, Kickers, and Transaction Structure, in NOMOS XXVII: CRMINAI JUSTICE 313 (J. Ronald Pennock \& John W. Chapman eds., 1935); Alvin K. Klevorick, Legal Theory and the Economic Analysis of Torts and Crimes, 85 CoLUM. L. REv. 905, 907-08 (1985); Alvin K. Klevorick, On the Economic Theory of Crime, in NOMOS XXVII: CRIMINAL JUSTICE, supra, at 289.

5. Robert Cooter, Prices and Sanctions, 84 COLUM. L. REV. 1523 (1984). I recognize, of course, that punitive damages are an exceptión to this generation. See infre note 26.

6. One can also describe this difference as that between "optimal" and "total" deterrence. See Jason S. Johnston, Punitive Liability: A New Paradigm of Efficiency in Tort Law, 87 CoLUM. L. REV. 1385 (1987); Alan $\mathrm{H}$. Scheiner, Note, Judicial Assessment of Punitive Damages, The Seventh Amendment and The Politics of Jury Power, 91 COLUM. L. REv. 142, 173-75 (1991). To illustrate, the optimal amount of fraud is zero, see Ackerman v. Schwartz, 947 F.2d 841, 847 (7th Cir. 1991), but the same cannot be said for pollution, which is an inevitable byproduct of industrial society. On this basis, fraud is a natural candidate for criminal penalties, and nonfraudulent (i.e., negligent) pollution for civil penalties. In addition, there are also crimes where the gain or benefit to the criminal actor is wholly illicit (the obvious example is the crime of rape), and thus a mere "pricing" policy produces the morally objectionable result that the defendant can benefit. Hence, a total deterrent approach is necessary. See infra note 28. 
"pricing"/"prohibiting" distinction is probably consistent with the general public's understanding of the difference between a tax and a criminal penalty. Indeed, precisely because this distinction is understood and accepted, I am skeptical of Professor Mann's suggestion that we should discard it by expanding the civil law to perform the same punitive functions as the criminal law.

We agree, however, on one theme: the criminal law should not be overused. This position stems not only from the usual fairness considerations, but also from a sense (at least on my part) that overuse will impair the criminal law's nondeterrent functions. Recent scholarship has emphasized the criminal law's socializing role as a system for moral education. ${ }^{7}$ In similar terms, economists have viewed the criminal law as an instrument for shaping preferences as well as for imposing costs. ${ }^{8}$ This "preference-shaping" role posits that the criminal law can and should affect not simply the rational actor's perception of the costs of crime, but also the actor's perception of the benefits from crime. To perform this role, however, the criminal law's scope must be limited because society's capacity to focus censure and blame is among its scarcest resources. Thus, I would seek to reduce the scope of the criminal law by focusing it on a limited range of misbehavior. In contrast, Professor Mann seems to propose only procedural, not substantive, limitations. Although he would encourage less frequent resort to the criminal law by offering public enforcers the alternative of broadly overlapping punitive civil penalties, this strategy does not "shrink" the scope of the criminal law, but only the frequency of its actual use (and only if his behavioral premises are correct).

Those who suggest that substantive limits can be placed on the scope of the criminal law face an obligation that Professor Mann does not: to describe, at least in principle, the conceptual limits that should be recognized and to determine whether their attainment is feasible. This Comment approaches that task in four stages. Part I surveys the recent expansion of the criminal law into domains previously thought civil in character. Part II assesses whether conceptual distinctions between civil and criminal deterrence are still possible once we acknowledge that tort law has a preventive purpose. Part III considers the behavioral effects of broadly empowering governmental enforcers to choose between civil and criminal sanctions (as Professor Mann proposes). Part IV then tentatively assesses what incremental steps might be taken to reestablish a civil/criminal border.

7. See TOM R. TYLER, WHY PEOPLE OBEY THE LAW (1990) (employing survey research to find that public complies with law largely because of its perceived moral legitimacy, not its deterrent threat). For a fuller discussion of the criminal law as a system of moral education, see John C. Coffee, Jr., Does "Unlawful" Mean "Criminal" ?: Reflections on the Disappearing Tort/Crime Distinction in American Law, 71 B.U. L. REV. 193 (1991).

8. See Kenneth G. Dau-Schmidt, An Economic Analysis of the Criminal Law as a Preference-Shaping Policy, 1990 DUKE L.J. 1. A number of the economic concepts used in this article were first articulated by either Professor Dau-Schmidt or Professor Johnston. See Johnston, supra note 6. 


\section{The Paradigms BluR: The ENCROACHMENT OF tHE CRIMINal LaW ON THE Civil LAW}

Most commentators acknowledge that the following attributes tend to distinguish the criminal law from the civil law: (1) the greater role of intent in the criminal law, with its emphasis on subjective awareness rather than objective reasonableness; (2) the criminal law's focus on risk creation, rather than actual harm; (3) its insistence on greater evidentiary certainty and its lesser tolerance for procedural informality; (4) its reliance on public enforcement, tempered by prosecutorial discretion; and (5) its deliberate intent to inflict punishment in a manner that maximizes stigma and censure. ${ }^{9}$ In contrast, tort law usually seeks only to force defendants to internalize the social costs that their conduct imposes on others. ${ }^{10}$ Its focus then is on harm, not blame. Professor Mann mentions most of these points (and others), and his discussion is instructive.

But there is one important difference that he largely ignores: criminal laws are legislative acts, while the civil law is largely judge-made. Early in the legal history of the United States, the separation of powers doctrine was interpreted to bar federal judges from creating common law crimes (as they did in Great Britain). ${ }^{11}$ But even apart from our unique constitutional context, in all common law countries, advance legislative specification today constitutes a fundamental prerequisite to a criminal prosecution.

In contrast, the civil law is always developing through judicial enlargement, often in surprising ways. American courts create new torts on a daily basis, and new substantive legal principles are regularly applied retroactively. The concept of "fair notice" is less of a normative barrier in the civil context, because courts are usually dealing with the allocation of losses between the parties. Thus, the question in such a context is not whether to impose a substantial penalty on the defendant, but rather how to divide losses actually incurred between plaintiff and defendant. In any event, the important point is that if a legal prohibition were enacted as both a criminal and a civil rule, there is a greater likelihood that it would experience judicial expansion-first in its civil law setting, but eventually (on a catchup basis) in its criminal setting. Moreover, judicial lawmaking inevitably tends to result in standards with a decidedly soft-edged, fuzzy quality. This imprecision is consistent with the natural desire of judges

9. See, e.g., Coffee, supra note 7; Robert W. Drane \& David J. Neal, On Moral Justifications for the Tort/Crime Distinction, 68 CAL. L. REV. 398, 402-03 (1980); Richard A. Epstein, Crime and Tort: Old Wine in New Bottles, in Assessing tHE CRIMINAL: REstTTUTION, RETRIBUTION, AND THE LEGAL PROCESS 231, 248-54 (Randy E. Barnett \& John Hagel III eds., 1977).

10. Learned Hand's great contribution to the law of torts was the formulation of a legal nule that essentially did this (and no more). See United States v. Carroll Towing, 159 F.2d 169, 173 (2d Cir. 1947) (defendant's obligation is to invest in precautions up to point where marginal costs to actor equal marginal benefits to society in terms of reduced losses to victims).

11. See United States v. Coolidge, 14 U.S. (1 Wheat.) 415 (1816); United States v. Hudson \& Goodwin, 11 U.S. (7 Cranch) 32 (1812). 
to leave themselves discretion and flexibility in future cases. Consider, for example, Cardozo's classic phrase: "A trustee is held to something stricter than the morals of the market place. Not honesty alone, but the punctilio of an honor the most sensitive, is then the standard of behavior." honor" standard is soft-edged and aspirational. Because such a standard can never be fully realized nor even defined with specificity in advance, it seems self-evident that it should not be criminalized.

Recently, however, this standard has been criminalized to an astonishing degree. Mail and wire fraud cases that have equated breaches of fiduciary duty with an illegal "scheme to defraud" present the best illustration of this phenomenon of the criminal law's encroachment on the civil law. During the 1970's, without any statutory change in the law, courts began to hold-first in cases involving public officials and then in cases involving all types of private fiduciaries - that a knowing breach of fiduciary duty could amount to a "scheme to defraud" for purposes of the mail and wire fraud statutes. ${ }^{13}$ These cases made any undisclosed conflict of interest criminal if the defendant occupied a fiduciary or similar relationship. ${ }^{14}$ This use of the criminal sanction to enforce fiduciary duties reflects the simplistic view that any desirable legal standard should be enforced by the strongest available sanction: namely, the criminal law. Obviously, advocates of this approach fail to understand how remedial law can affect and distort substantive law, changing both how it is read and how it will develop. For example, if the ethical standards of bar associations and other private groups were regularly criminalized, it would not take long before these groups began to self-insure by adopting less aspirational standards. Yet, as I read Professor Mann, his prescription advocates the overlap of civil and criminal law in the hopes that the availability of more punitive civil penalties for the same conduct would dissuade prosecutors from resorting to criminal sanctions. In contrast, my view is that the overlap is itself a problem. Thus, in my view, a breach of a fiduciary duty, standing alone, should not fall within the purview of the criminal law at all (although it could certainly be subject to civil penalties). ${ }^{15}$

12. Meinhard v. Salmon, 164 N.E. 545,546 (N.Y. 1928).

13. See 18 U.S.C. $\$ \S 1341,1343$ (1988). I have discussed the expansion of these statutes at length elsewhere. See John C. Coffee, Jr., From Tort to Crime: Some Reflections on the Criminalization of Fiduciary Breaches and the Problematic Line Between Law and Ethics, 19 AM. CRIM. L. REV. 117 (1981); John C. Coffee, Jr., The Metastasis of Mail Fraud: The Continuing Story of the "Evolution" of a WhiteCollar Crime, 21 AM. CRIM. L. REv. 1 (1983).

14. The growth, decline, and eventual reemergence of this "intangible rights" doctrine has been discussed at length elsewhere. McNally v. United States, 483 U.S. 350 (1987), sharply cut back on the expansion of these statutes. Congress, however, has largely overridden McNally. See 18 U.S.C. $\$ 1346$ (1988). For a recent update on the case law, see Donna M. Maus, Note, License Procurement and the Federal Mail Fraud Statute, 58 U. CHI. L. REV. 1125 (1991).

15. Again, this is an area where criminalizing a civil law standard may distort its development. Once courts understand that fiduciary duties can be criminally enforced so that a simple undisclosed conflict of interest can become criminal, they may begin to become more cautious in articulating fiduciary duties, using not the traditional rhetoric of undivided loyalty, but the narrower formulations of the corporate lawyer. 
Nor is this example of the "intangible rights" doctrine unique. The law defining insider trading is also wholly judge-made, ${ }^{16}$ and has expanded recurrently. A similar expansion has occurred in the case of the Hobbs Act and other major "white-collar" crime statutes. ${ }^{17}$ To be sure, at times, courts have also contracted the law. The crucial point, however, is that the important substantive developments in either direction have recently been judge-made to an extraordinary degree. ${ }^{18}$

At the same time that courts have begun to apply the penalties of the criminal law to legal standards that evolved within the civil law, they have also shown an increasing tendency to abandon some of the most important limits on the criminal law. For example, in some areas of white-collar criminal law there is a noticeable trend toward the acceptance of vicarious responsibility. ${ }^{19}$ Additionally, although private enforcement of the criminal law has long been rejected in the United States, where prosecutorial discretion is venerated, a trend toward the delegation of this discretion is evident in recent legislation empowering both civil authorities and private individuals to seek quasi-criminal penalties. ${ }^{20}$ These trends would accelerate if the substantive content of the criminal law could be enforced in civil and administrative proceedings. In this respect, I view Professor Mann's proposal as a road map to overcriminalization.

A principal cause of overcriminalization is the profligate extension of the criminal sanction to cover all rules lawfully promulgated by an administrative agency. It has become the common statutory pattern in the United States for a statute establishing an administrative agency to provide that any willful violation of the rules adopted by the agency constitutes a federal felony. ${ }^{21}$ As

16. While the federal securities law creates a private right of action with respect to insider trading, Securities Exchange Act of 1934 , \$ 20A, 15 U.S.C. $\$ 78 \mathrm{t}-1$ (1988), no statutory definition of insider trading has been attempted. The crime is sometimes prosecuted under the mail and wire fraud statutes and sometimes under the securities laws. Compare Carpenter v. United States, 484 U.S. 19 (1987) with United States v. Chestman, 947 F.2d 551 (2d Cir. 1991) (en banc), petition for cert. filed, 60 U.S.L.W. 3500 (U.S. Jan. 1, 1991) (No. 91-1085).

17. See United States v. Kattar, 840 F.2d 118 (1st Cir. 1988); United States v. Covino, 837 F.2d 65 (2d Cir. 1988); United States v. Paschall, 772 F.2d 68 (4th Cir. 1985); United States v. Williams, 621 F.2d 123 (5th Cir. 1980); Charles F.C. Ruff, Federal Prosecution of Local Corruption: A Case Study in the Making of Law Enforcement Policy, 65 GEO. L.J. 1171 (1977). Again, there are signs that the Supreme Court may be reining in the Hobbs Act, as it did in the case of mail fraud. See McCormick v. United States, 111 S. Ct. 1807 (1991); United States v. Evans, 910 F.2d 790 (11th Cir. 1990), cert. granted, 111 S. Ct. 2256 (1991).

18. McCormick, 111 S. Ct. 1807, McNally, 483 U.S. 350, and Dirks v. SEC, 463 U.S. 646 (1983), have all cut back on broader theories of liability. Meanwhile, Congress has remained largely paralyzed. The single exception is its passage of a one-sentence statute, 18 U.S.C. $\$ 1346$ (1988), reversing much of McNally.

19. See, e.g., United States v. Frezzo Bros., Inc., 602 F.21 1123, 1130 n.11 (3d Cir. 1979); United States v. Starr, 535 F.2d 512 (9th Cir. 1976); United States v. Y. Hata \& Co., 535 F.2d 508 (9th Cir. 1976). For a discussion of the current state of the law, see Coffee, supra note 7, at 213-15.

20. For a detailed review, see Bruce A. Green, After the Fall: The Criminal Law Enforcement Response to the S\&L Crisis, 59 FORDHAM L. REV. 155, 176-78 (1991) (analyzing provisions of Financial Institutions Reform, Recovery and Enforcement Act).

21. See, e.g., Securities Exchange Act of 1934, § 32(a), 15 U.S.C. § 78ff (1988); Securities Act of 1933, $\S 24,15$ U.S.C. $\S 77 \times$ (1988); Investment Company Act of $1940, \S 49,15$ U.S.C. $\S 80 \mathrm{a}-48$ (1988); Investment Advisers Act of 1940, § 217, 15 U.S.C. $\$ 80 \mathrm{~b}-17$ (1988). 
a direct result, one estimate places the number of federal regulations currently punishable by criminal penalties at over $300,000 .{ }^{22}$ Technical offenses-such as "stock parking," net capital, or margin rule violations (to give only examples from the federal securities laws)-are thus potentially punishable under the same statutory provisions that prohibit fraud. Civil penalties make the greatest sense in this area-as a replacement for criminal charges, not simply as a discretionary prosecutorial alternative. Optimally, federal statutes creating an agency or setting forth some comprehensive system of regulation should still contain criminal penalties-but only for more serious crimes, such as willful fraud, bribery, or reckless endangerment. In these cases, the statutory definition of the crime would require proof of actual moral culpability and not simply the equivalent of spitting on the sidewalk.

A recurring pattern emerges. Public concern about a newly perceived social problem - the environment, worker safety, spousal abuse-triggers a societal reflex in the United States: the adoption of new criminal legislation that typically elevates any knowing or willful violation of the statutory regime to the status of an indictable felony. No doubt these social problems are serious (and no attempt to minimize the injuries from them is intended). But as this process of reflexive criminalization continues, its little-noticed consequence is to expose a significant portion of the population of the United States to potential entanglement with the criminal law during the ordinary course of their professional and personal lives. ${ }^{23}$ Actual use of the criminal sanction might remain rare, but it is the threat of its use that must be chiefly considered in evaluating the degree of freedom within a society. To be sure, some may justify pervasive use of the criminal sanction based on simple cost/benefit reasoning: the loss to those imprisoned is less than the harm thereby averted through specific and general deterrence. Yet this analysis depends on a myopic social cost accounting. Even if the deterrent effect gained under such a system of enforcement exceeded the penalties actually imposed, additional costs need to be considered, including the fear and anxiety imposed on risk-averse individuals forced to live under the constant threat of draconian penalties. These citizens would bear not only the risks of false accusation and erroneous conviction, but also the constant fear that they might commit an unintentional violation. ${ }^{24}$ Ultimately, if we

22. This estimate was made by Stanley Arkin, a well-known defense practitioner in this field. See Coffee, supra note 7, at 216 n.94.

23. This was precisely the concem of Professor Packer, writing over 20 years ago. See HERBERT L. PACKER, THE LIMTSS OF THE CRIMINAL SANCTION (1968). In his view, the principle of fair notice was chiefly intended to permit ordinary citizens to be able to arrange their affairs so as to avoid entanglement with the criminal law (or presumably with other forms of extreme penalties).

24. Because it is a generally recognized principle that "ignorance of the law is no excuse," unintentional violations are more likely to result from the use of the criminal law as a backstop to enforce technical rules and regulations. Those who believe these costs are minor should consider the following heuristic example: Suppose a utilitarian society adopts a penalty of capital punishment for speeding, on the plausible assumption that it would greatly reduce the 50,000 traffic fatalities incurred annually in return for only a few executions. The principal cost ignored by such a social calculus is the fear engendered among drivers that they might negligently break this law. In addition, overdeterrence and consequent efficiency losses would result as the 
measure the success of the criminal law exclusively in terms of the number of crimes prevented, we could wind up, in Herbert Packer's memorable phrase, "creating an environment in which all are safe but none is free." threat of the criminal law's use should be curtailed, Professor Mann's proposals do little or nothing to reduce that threat.

\section{The Paradigms Distinguished: Pricing Versus Prohibiting}

Professor Mann's key assumption is that once one acknowledges that the civil law also deters by awarding more-than-compensatory relief, the penalties the civil law administers become indistinguishable from those that the criminal law administers. As a prediction, this may unfortunately prove to be correct, but his claim need not be accepted as a matter of logic. To be sure, Professor Mann is entirely accurate in describing the current state of the constitutional law on the civil/criminal distinction as chaotic. The Supreme Court has begun to talk about punishment and deterrence as if no distinction existed ${ }^{26}$ At times, it has seemingly equated punitive damages, civil penalties, and criminal fines. ${ }^{27}$ But these scattered statements do not express any coherent judicial theory, and thus they only raise, rather than resolve, the central policy question on which I wish to focus: can a civil/criminal distinction be resurrected? Or should we accept the two bodies of law as simply interchangeable means to the same ends?

To draw a possible line of distinction, it is useful to return to the difference between prices and sanctions. Assume that a correctly calculated "price" forces the actor to internalize the social costs of an activity. Thus, if the actor's business imposes external costs on others (whether in the form of industrial accidents, pollution, or injuries from unanticipated side effects or defects in the product), tort law often requires the actor to pay these external costs to the

risk-averse turned to public transportation or engaged in inefficiently low-speed driving. Still, the greatest cost would be the anxiety that such a legal rule would visit on those unavoidably subject to it.

25. See PACKER, supra note 23 , at 65 .

26. In Pacific Mut. Life Ins. Co. v. Haslip, 111 S. Ct. 1032 (1991), the Court upheld a punitive damages award. But the Court suggested that such an award could violate due process if not checked by a judicial review intended to ensure that "the award does 'not exceed an amount that will accomplish society's goals of punishment and deterrence."' Id. at 1045 (quoting Green Oil Co. v. Hornsby, 539 So. 2d 218, 222 (Ala. 1989) and Wilson v. Dukona Corp., 547 So. 2d 70, 73 (Ala. 1989)). Thus, Haslip at least hints that a merely "grossly excessive" standard, which does not provide more limiting standards for reviewing punitive damages, is constitutionally suspect. See also Mattison v. Dalles Carrier Corp., 947 F.2d 95 (4th Cir. 1991) (finding punitive damage award violated due process); Union Nat'l Bank v. Mosbacher, 933 F.2d 1440 (8th Cir. 1991) (remanding for determination whether punitive damages violated due process).

27. In particular, the Court has recently emphasized that punitive damages are intended "to punish defendants for torts committed with fraud, actual malice, violerice, or oppression." Molzof v. United States, 112 S. Ct. 711, 715 (1992); see also Tull v. United States, 481 U.S. 412, 422 n.7 (1987) ("The more important characteristic of the remedy of civil penalties is that it exacts punishment .... Thus, the remedy of civil penalties is similar to the remedy of punitive damages . ..."); Gertz v. Robert Welch Inc., 418 U.S. 323,350 (1974) (punitive damages "are private fines levied by civil juries to punish reprehensible conduct and deter its future occurrence."). 
victims, thereby giving the actor a greater incentive to take precautions. In theory, the rational actor will take precautions up to the point where the marginal cost of further precautions equals the marginal benefit from reducing the actor's expected liability. Legal rules that exact a "price" thus straddle the deterrent/compensatory watershed because they seek to do both; that is, they seek to make victims whole and to induce precautions that avert future injuries. Clearly, their purpose is not prohibitory in the sense of forbidding entirely the activity in question by imposing penalties greater than the social costs created by the activity. Indeed, if the defendant's benefit from the conduct exceeds the victim's loss (adjusted to reflect the limited likelihood of apprehension), the defendant is free under optimal deterrence theory to engage in conduct that harms others at will, so long as the defendant pays all compensation. ${ }^{28}$

A social cost ceiling thus bounds an "optimal deterrence" or "pricing" approach. However, imposing penalties that exceed the compensatory relief victims would receive does not mean that this social cost ceiling is being exceeded or that "punishment" (in the constitutional sense) is necessarily being inflicted. For example, victims often will not know of their injury or they will not come forward to seek compensation (for any of a variety of reasons, including the prohibitive costs of litigation). In these cases, the same incentive to take optimal precautions will nevertheless still result, if either (1) the state exacts an equivalent civil penalty, or (2) a private claimant receives a morethan-compensatory award in the same aggregate amount as the compensatory damages would have been had all the injured sued and recovered. In short, the economic effect of such a penalty is still to induce the same higher level of care and precaution that essentially balances the actor's private costs with the social costs of the activity. Obviously, because the penalty is not redistributed to the victims, it does not provide compensation. Thus, although the penalty appears to fall on the deterrence side of Professor Mann's watershed, it is arguably not punitive in the same way that criminal penalties that seek to deny the defendant any benefit whatsoever from the conduct are punitive. In short, such an example illustrates a penalty level that is deterrent, but not punitive.

If a civil penalty equal to the social cost of the behavior can be described as nonpunitive, then arguably the full constitutional safeguards applicable to criminal prosecutions need not apply. Of course, it must be conceded that damage estimation is an inexact science, and such a limit on civil penalties could be quite high. Sometimes the social costs from crime may include thirdparty effects that may be substantially larger (or smaller) than the compensatory

28. See WILLIAM R. LANDES \& RICHARD A. POSNER, THE ECONOMIC STRUCTURE OF TORT LAW 15360 (1987). Most theorists recognize that some forms of pleasure or utility may be illicit and should be subject to total deterrence. $C$. id. at 156-57 \& n.9; STEVEN SHAVELL, ECONOMIC ANALYSIS OF ACCIDENT LAW 147-48 (1987). Some of these theorists argue, however, that total deterrence should never apply to profit-making activities in markets. That is not my claim. Rather, I argue that the criminal law should be oriented towards "total deterrence" and the civil law toward "optimal deterrence." What should fall within each of these two categories is, of course, debatable. 
relief the civil law would award to injured victims. Consider, for example, the negligent sales of securities. The social loss here is not just the monetary loss to investors (which is a wealth transfer and hence only a private loss), but the higher cost of capital that other issuers may have to bear because investors are now marginally more skeptical of the accuracy of disclosures made by all issuers. ${ }^{29}$ These other issuers suffer an externality caused by the wrongdoer's conduct, but they have no private remedy. Thus, civil penalties that seek to internalize social costs are not necessarily related to the compensatory damages that the civil law would assess.

Where then is the watershed between civil and criminal penalties? Elsewhere, I have suggested that it lies in the distinction between "pricing" and "prohibiting." 30 The legal system sometimes attempts not simply to force actors to internalize the social costs of their activities, but to deny any gain to the defendant from the activity. In such cases, the optimal level of the activity is judged to be zero because the activity is deemed to lack social utility in any form (even though it may produce utility for the actor). For example, the civil law only taxes most industrial polluters because it wants them to reduce their level of pollution - not to cease production altogether. In contrast, the criminal law typically wants to bar some activities entirely, for example, theft, rape, murder - and some forms of environmental pollution. This approach (which some call "total deterrence") sees the victim as having a moral right to be free of the defendant's conduct, regardless of its profitability or its greater utility to the defendant or society. ${ }^{31}$

To generalize, let us say then that characteristically the criminal law prohibits, while the civil law prices. This statement is not only a positive description of the law, but also a normative assertion. The pursuit of "total deterrence" should be carefully limited, with the state clearly identifying in advance the proscribed conduct and with potential defendants receiving fair warning. Identifying the forms of conduct wholly lacking in social utility and thus subject to "total deterrence" seems quintessentially a legislative act. Put differently, courts are entitled to some discretion in pursuing optimal deterrence but not in deciding when to pursue total deterrence. In this light, the real problem with punitive damages is both that they represent a retrospective pursuit of total deterrence and that they lack the legitimacy that only the legislature can confer. The decision that the benefits derived by the defendant are so perverse, immoral, or otherwise unacceptable as to be wholly disregarded by society (and thus "prohibited" by a total deterrence policy) should require a greater communal consensus than a judicial or a jury decision represents. Viewed this way, greater vagueness in the civil law is justified precisely

29. See, e.g., Ackerman v. Schwartz, 947 F.2d 841, 846-47 (7th Cir. 1991).

30. Coffee, supra note 7 , at 225-28.

31. See Johnston, supra note 6; Scheiner, supra note 6, at 175. 
because the civil law is only "pricing" behavior (that is, estimating costs), which requires no new social consensus.

Still, a problem with this dichotomy is that through punitive damages the civil law can pursue a total deterrence strategy. But this recognition only explains why I am wary of Professor Mann's willingness to legitimate punishment as a goal of the civil law. Above all, I doubt that administratively imposed penalties will ever reflect the same scrupulous concern for the defendant's rights as displayed in a criminal trial. Even in the light of the doctrinal convergence that he demonstrates, I would still cling to this normative hope: when the legislature uses an abrupt, discontinuous increase in penalty levels to prohibit, rather than to price, behavior, such a use of deterrence should trigger at least some of the constitutional safeguards applicable to a criminal trial.

Still, this statement faces an obvious operational problem: if the social costs of legitimate behavior can be high, how does one distinguish attempts to price from attempts to prohibit? A recent Supreme Court decision hints that the Court wants a bright-line distinction before it attempts to distinguish between optimal and total deterrence. ${ }^{32}$ On occasion, a statute's legislative history may answer this question, but the most practical guide is whether the penalty has been intentionally enhanced in order to deny any possibility of benefit to the defendant. If all else fails, the ultimate inquiry might be whether the statute reflects a judgment that the activity in question so lacked positive social utility that its optimal level was zero. In such cases, one can presume the legislature intended to prohibit rather than price such behavior. Often, this is clear. Theft, for example, clearly lacks social utility because it forces society to expend resources on costs, such as locks, security devices, and enforcement systems, that would otherwise be unnecessary. Similarly, Judge Easterbrook recently opined that "[t]he optimal amount of fraud is zero." ${ }^{.33}$ Clearly, however, the optimal level of pollution or worker accidents is above zero, because to reduce these levels to zero would require unlimited expenditures on precautions. In these cases, where the fair inference should be that the legislature only intended to "price" the negligent behavior, the assessment of civil penalties would not have to comply with the higher procedural standards applicable to criminal or quasicriminal fines.

To sum up this part, the line between the civil and criminal law might be drawn in terms of whether financial penalties seek simply to force actors to internalize the full social costs of their behavior or whether they seek to deprive the actor of any gain whatsoever from the illicit activity. Traditionally, the criminal law has pursued the latter end, as the pervasive use of capital punishment for most felonies and the tradition that the felon's property escheated to

32. See Molzof v. United States, 112 S. Ct. 711, 717 (1992) (noting that "Government's interpretation of punitive damages would be difficult and impractical to apply" where it sought to deem as punitive damages any form of compensation for nonpecuniary injuries).

33. See Ackerman v. Schwartz, 947 F.2d at 847. 
the crown seems to demonstrate. Although this proposed line between "pricing" and "prohibiting" would still permit civil penalties of a magnitude likely to deter, it frames a different standard than the compensatory/deterrent dichotomy that Professor Mann argues courts have used in the past to rationalize civil penalties of intermediate severity. Under this proposed social cost ceiling on civil penalties, the monetary penalty levied by the state would not need to compensate actual victims, but would primarily induce the taking of precautions. Also, the receipt of more-than-compensatory damages by a private plaintiff would prove nothing of significance, because the plaintiff-private or public-should be seen as the delegated agent of the state (or, in more traditional terminology, as a private attorney general). Only when the penalty exceeded the maximum social cost ascribable to the activity would the civil/criminal boundary necessarily be crossed.

From a policy perspective, this distinction between "pricing" through civil penalties and "prohibiting" through criminal penalties leads to an obvious policy question: why should society ever prefer prices over the more effective weapon of sanctions? One reason is obvious. When society wants not to proscribe the activity, but only to reduce its level, it should use prices. Another answer, given by Professor Cooter, is subtler: the choice depends on whether it is less costly to determine the correct standard of behavior or to determine the social costs caused by a departure from that standard..$^{34} \mathrm{He}$ argues that because behavior is relatively responsive to changes in price levels, the use of prices is preferable when society wishes to reduce the level of an activity, but does not feel able to define the precise standard of behavior it wants. In contrast, the use of sanctions makes sense when society can precisely articulate the desired standard of conduct, because then prices have the disadvantage of permitting low-cost departures from that standard so long as the degree of departure is modest. Interestingly, this prescription correlates closelly with the earlier noted tendency for civil law rules to be soft-edged and fuzzy in comparison to criminal law rules. Inherently, the civil law contemplates modest, low-cost departures from its norms, because it only "prices" such departures and does not "prohibit" them. The criminal law, in contrast, does not even permit small departures, absent the availability of some special affirmative defense. Again, this analysis suggests the dangers of allowing the criminal law to encroach on the civil law insofar as soft-edged legal rules may have been intended to be enforced based primarily on the extent of the departure from them, not simply on the fact of a departure.

While Professor Cooter presents the choice between prices and sanctions as essentially resting on relative information costs, ${ }^{35}$ the underlying difference may instead be society's relative moral certainty. If society is certain on moral

34. See Cooter, supra note 5, at 1533.

35. Id. 
grounds of the precise standard it wants to enforce and wishes to tolerate few departures, then sanctions work better. If, on the other hand, uncertainty or value tradeoffs exist that cannot be resolved in advance, then prices may be preferable. The overall structure this relationship points toward is a penumbra of civil penalties around an inner core of fundamental moral precepts enforced by sanctions. This structure, however, differs considerably from Professor Mann's proposal, in which enforcers have near-complete discretion to choose between criminal and civil penalties.

\section{A Policy Appraisal: The Problems With Overlapping Criminal and Civil Penalties}

To this point, I have argued only that a conceptual line could be drawn between civil and criminal penalties based on whether a particular penalty sought only to internalize the external costs the actor imposed on others or whether it sought to prohibit the conduct itself. The larger policy question is whether such a line should be drawn. If it were drawn, courts might find some penalties, although officially denominated as civil, sufficiently criminal or quasi-criminal in nature to invoke some or all of the constitutional protections afforded the criminal defendant.

Why is it important to distinguish civil from criminal penalties when we could instead, as Professor Mann suggests, adopt a "middleground jurisprudence" applicable to all more-than-compensatory penalties? A partial answer lies in the incentive effects of overlapping civil and criminal penalties. The first and most obvious incentive for regulators confronting parallel civil and criminal penalties is to use the civil option for cases in which either the evidence or the legal merits are weak. ${ }^{36}$ Procedural informality benefits the prosecution. The prosecution obtains a decided advantage when it can try its case in an extrajudicial proceeding before an administrative law judge operating under informal rules of procedure and evidence. ${ }^{37}$ Indeed, the one common denominator in the SEC experience with administrative law judges is familiar: the SEC always seems to win before its in-house judges. ${ }^{38}$ Beyond the home court advantage,

36. Others have made the same point. See Green, supra note 20 , at 179.

37. The recent settlement accepted by Kaye, Scholer under which it will pay $\$ 41$ million in damages to the Office of Thrift Supervision (OTS) illustrates the procedural leverage the government gains in an administrative proceeding on its home court. See Stephen Labaton, Law Firm will Pay a \$4I Million Fine in Savings Lawsuit, N.Y. TIMES, Mar. 9, 1991, at A1. Other law firms sued by the OTS in judicial actions have neither settled nor had their assets frozen. While the use of an asset freeze may have precipitated Kaye, Scholer's sudden capitulation (after months of extended and adversarial negotiations), the relevant point here is that it is unlikely that the government could have obtained such an extreme pretrial order from an Article III judge. For the extreme case in which an ex parte order to pay $\$ 21$ million in restitution by the next day was upheld in the context of an administrative proceeding, see Spiegel v. Ryan, 946 F.2d 1435 (9th Cir. 1991).

38. An American Bar Association task force studied 62 SEC administrative cases over a five-year period and found that administrative law judges upheld the SEC in 58 of the cases. See ABA Task Force Survey Finds ALJs Almost Always Uphold SEC Charges, 21 Sec. Reg. \& L. Rep. (BNA) No. 40, at 1531 
public enforcers also gain the ability to prove their cases simply by a preponderance of the evidence, rather than beyond a reasonable doubt, and to evade the jury's ability to nullify an overly harsh law. As a result, civil penalties, particularly when administratively imposed, could provide the means for evading constitutional safeguards.

A less obvious reason why overlapping criminal and civil penalties may not "shrink" the criminal law involves two less visible facts of governmental life: the inevitability of bureaucratic competition and the struggle for credit. An implicit assumption underlying proposals to expand civil penalties is that federal criminal cases involving regulatory violations result primarily from criminal referrals made by administrative agencies to federal prosecutors. On this premise, if administrative enforcers were armed with powerful civil penalties, Professor Mann reasons that they might refer less of their enforcement cases to federal prosecutors, retaining for in-house discipline all but the most egregious violations. Although this reasoning may have some validity, it is naive in at least two important respects. First, many cases involving regulatory violations originate within the U.S. Attorney's office. They arise not from an external agency referral, but spontaneously, through the predictable dynamics of plea bargaining. Because the principal currencies in plea bargaining are information and cooperation, a defendant desiring favorable treatment needs as a practical matter to implicate someone else, preferably someone more important. The resulting parade of falling dominoes can move in unanticipated directions, leapfrogging over jurisdictional and subject matter boundaries. Thus, a bribery investigation might suddenly branch out into a regulatory crime, or a fraud case could become a criminal tax case as well. Authorizing enhanced civil penalties will not "shrink" these cases, because federal prosecutors want credit for the cases they have uncovered.

Predictions that the criminal law will "shrink" in the wake of enhanced civil penalties also seem unrealistic in light of the bureaucratic incentives to bring criminal cases. Even if enhanced civil penalties could be assessed more quickly at lower cost and with a lower reversal rate on appeal, the agency loses the publicity and public drama that uniquely attends the criminal process. Public attention is important to an agency for a variety of reasons. Public visibility may help the agency communicate its self-image as a tough, "no-nonsense" enforcer. That image may in turn assist the agency in obtaining its desired budgetary allocation, in recruiting new personnel, or simply in maintaining morale among its officials. In addition, such an image may generate greater general deterrence than a substantial number of low-visibility civil penalties, even if the aggregate amount of the civil penalties imposed were higher.

(Oct. 13, 1989). These judges seem to share the enforcement mission of their agencies. I am aware that the pattern is different in the case of some other agencies (such as the Social Security Administration), but these are not public enforcement agencies. 
Still, a deeper reason explains why agencies are likely to persist in seeking criminal sanctions even if parallel civil penalties were available. No agency believes that violations of its rules are simply regulatory offenses that lack inherent moral culpability. Whatever the agency-EPA, SEC, OSHA, FDA-it is a safe bet that its staffers believe that their agency's rules protect vital public interests. To communicate this view, the agency needs the public morality drama that only the criminal law affords. Indeed, the limited empirical evidence on public attitudes toward white-collar crimes suggests that the public learns what is criminal from what is punished, not vice versa. ${ }^{39}$ That is, the use of the criminal sanction changes public perceptions of the severity of an offense, increasing the public's estimate of its inherent culpability. Such evidence underscores the socializing power of the criminal law, but also explains in turn why there are pressures for its overuse. From the agency's perspective, any legislative failure to authorize criminal penalties for violations of its rules and regulations depreciates its mission-particularly in contrast to other agencies enjoying access to criminal penalties.

A predictable reply to these assertions is that prosecutors have no incentive to bring petty or technical cases, in part because they may incur judicial displeasure. This is a partial truth, but one offset by a corresponding perverse incentive. White-collar investigations take time, typically extending a year or more from when a U.S. Attorney's office commences a formal investigation to indictment. Such lengthy investigations require a substantial commitment of resources. The personal commitment of Assistant U.S. Attorneys actually conducting the investigation may be even more costly since most of them anticipate spending only a limited period of time in the office. Suppose, for example, that a two-year investigation into a suspected "traditional" crime (such as bribery or fraud) fails to turn up sufficient evidence for an indictment. But assume further that, as is almost invariably the case, some breach of an agency's rules and regulations surfaces. At the outset of the investigation, such evidence of a low-gravity violation would not have interested the prosecutors; but now, having sunk years of time into what is otherwise a dry well, the temptation arises for them to justify their efforts by indicting on the technical violations. ${ }^{40}$ Good prosecutors resist this urge to produce an indictment at all costs, but not all prosecutors live up to this standard. In short, technical violations may be criminally prosecuted because they provide a face-saving way of rationalizing failure. In addition, they allow the prosecutor who needs cooperation from a critical witness to pressure the witness to provide the necessary

39. For an excellent analysis of the interactive role between the use of criminal punishment and the public's perception of what is criminal, see Harry V. Ball \& Lawrence M. Friedman, The Use of Criminal Sanctions in the Enforcement of Economic Legislation: A Sociological View, 17 STAN. L. REV. 197, 213 (1965).

40. For an experienced former federal prosecutor's assessment that this regularly occurs, see Daniel J. Hurson, Limiting the Federal Mail Fraud Statute-A Legislative Approach, 20 AM. CRM. L. REV. 423, 433 (1983). 
evidence. Whatever the reason, the bottom line is that bureaucratic and careerist incentives exist for prosecutors to use technical violations as a basis for criminal prosecutions. No doubt their chosen tool serves them well, but the cost to society involves tolerating a heightened potential for selective prosecutions.

Finally, a structure of overlapping civil and criminal penalties as proposed by Professor Mann might have unintended effects on judicial behavior. It is far easier to expand precedents and make new law in civil cases than in criminal ones. If enforcers could choose at their discretion between civil and criminal penalties, they might use the civil route as a vehicle by which to advance novel theories, hoping to impose criminal penalties later, after establishing the new theory of liability. In addition, to the extent that there is a "first mover" advantage and decisions by administrative law judges can influence courts, this technique might be a very effective means for enlarging the scope of the criminal law. Take, for example, the persistent problem of defining "insider trading." Had the SEC been able at the outset to develop a body of expansive administrative precedents defining this term, it is likely that courts would have deferred to the Commission, given their lesser familiarity with the field. ${ }^{4 i}$ If so, overlapping civil and criminal penalties should expand, not contract, the criminal law.

\section{THE PARADIGMS Regained}

Both Professor Mann and I agree that the criminal law should be confined "to areas of clearly egregious behavior in which severely punitive civil monetary sanctions are ineffective. ${ }^{, 42}$ But how does one get there, when today an extraordinary percentage of federal regulations carry the potential threat of a criminal sanction? Professor Mann proposes enhanced civil penalties coupled with the enhanced procedural safeguards of his "middleground jurisprudence." However, this is an uncertain tradeoff. On one level, public enforcers might fear that what they lost in terms of foregone flexibility and procedural informality from such a tradeoff more than offset their gain in increased deterrent threat. Thus, administrative enforcers might be disinclined to use civil penalties if the process became, in their judgment, more cumbersome or costly.

Conversely, it is far from clear that halfway measures in terms of enhanced procedural safeguards truly benefit the defendant. For example, if a "middleground jurisprudence" were to require that administrative law judges employ an intermediate standard between the civil standard of "preponderance of the evidence" and the criminal standard of "proof beyond a reasonable doubt," such

41. In fact, the first case to define and proscribe insider trading was an administrative decision, and courts have uniformly deferred to it since (properly, in my judgment). See In re Cady, Roberts \& Co., 40 S.E.C. 907 (1961). At the time, the SEC had only limited powers to impose administrative civil penalties, and therefore the subsequent development of insider trading law was largely judicial.

42. See Mann, supra note 1 , at 1802 . 
an intermediate standard-for example, "clear and convincing evidence"-might represent little more than a symbolic gesture by the state in return for the defendants' sacrifice of their right to a jury trial. After all, such a standard has applied to civil commitment hearings without anyone believing that the respondent retains the same safeguards as in a criminal trial. The real inhibitions on use of the criminal sanction may be factors extrinsic to the formal due process model: (1) the high costs of a criminal trial, (2) the overloaded dockets of the criminal courts, (3) the relative independence of an Article III judge, and (4) the sheer unpredictability of juries and the possibility of jury nullification when the legal standard seemed overly severe. In contrast, administratively imposed sanctions tend to be cheap and predictable. Consequently, it seems an indeterminate question whether defendants would fare better under a legal regime permitting the civil imposition of very punitive penalties with only somewhat enhanced procedural safeguards.

What then is the alternative? Ideally, the Constitution could be read to require that "true" punishment (that is, penalties above the social cost ceiling described earlier) could be imposed only by Article III judges in proceedings where the defendant had the right to a jury trial. This would still permit administrative proceedings to levy lesser penalties, but would necessitate judicial imposition of the most draconian penalties. In contrast to Professor Mann's proposals, this approach would accentuate the difference between judicial and administrative penalties, not bridge it with his "middleground" jurisprudence. Unfortunately, little reason exists to think that the current Supreme Court will move in this sensible direction. ${ }^{43}$

Therefore, one must focus instead not on constitutional limits, but on enforcement incentives. Accordingly, to induce regulators to use civil penalties, it is necessary either to make civil penalties more attractive or criminal penalties less attractive to them. Thus, it may be necessary to accept informal procedures and not to raise due process standards significantly-except when the penalties become so severe as to amount to the functional equivalent of criminal penalties. From a cost-benefit perspective, the basic strategy should be to preserve (or create) a cost differential favoring civil penalties so that public enforcers will opt for their use. Such a cost differential is necessary

43. Recent decisions suggest that the Court is no longer fully committed to the position it took in Atlas Roofing Co. v. Occupational Safety \& Health Review Comm'n, 430 U.S. 442 (1977), that the legislature may provide for administratively imposed penalties that do not trigger the applicability of the Seventh Amendment. See Granfinanciera, S.A. v. Nordberg, 492 U.S. 33 (1989). Still Granfinanciera recognizes that "[i]f a claim that is legal in nature asserts a "public right' . . . then the Seventh Amendment does not entitle the parties to a jury trial if Congress assigns its adjudication to an administrative agency or specialized court of equity." 492 U.S. at 42 n.4. This ambiguous category of "public rights" creates an exception broad enough to encompass all civil penalties and thus to swallow the rule. As a result, if constitutional limitations are to be imposed on the gravity of the penalty that an administrative tribunal can impose, they are more likely to emerge from a constitutional reinterpretation of Article III. See Crowell v. Benson, 285 U.S. 22 (1932). At present, the trend remains strong in the opposite direction. See Akin v. Office of Thrift Supervision, 950 F.2d 1180 (5th Cir. 1992) (no right to jury trial in case where administrative agency orders $\$ 19$ million in restitution). 
because the higher penalties and greater public attention accorded to the criminal sanction create an inevitable benefit differential favoring their use. Given the greater deterrent payoff from criminal penalties, civil penalties can only compete by being cheaper and/or quicker. Yet it is exactly this cost differential that Professor Mann's proposals seem likely to erode.

An alternative means to the same end might seek to maintain the cost differential that favors civil penalties by reducing the deterrent benefit from prosecuting "regulatory" crime through the criminal process. The most direct means to this end would be to promulgate sentencing guidelines that established relatively low ceilings on the maximum penalties for such crimes (while maintaining high penalties for traditional, full "mens rea" crimes, such as fraud or perjury). Thus, it would become possible for public enforcers to obtain civil penalties that were higher than the corresponding criminal fines for "regulatory" crimes. No doubt, some incentives for criminal prosecutions would still remain. However, both the costs and the benefits of civil penalties could be made more attractive than criminal prosecutions to public enforcers for precisely those crimes that we wish to "shrink" out of the criminal law.

But who will bell the cat? Clearly, the legislature has little interest in "shrinking" the criminal law since it is the body most responsible for thoughtlessly expanding it. While some federal courts have recently shown an apparent distaste for "regulatory" prosecutions, ${ }^{44}$ there is no viable constitutional theory by which they can "shrink" the criminal law. Thus, the one agency that can affect this cost differential is the U.S. Sentencing Commission, but whether it has any incentive to do so remains an open question.

Another means of encouraging the use of civil penalties would be to require prosecutors to conform more strictly to the traditional requirements of the criminal law paradigm. This approach would imply that mens rea requirements be enforced more rigorously in criminal cases than in civil penalty assessments, and that a principle of lenity bar novel expansions of traditional statutory terms. A series of recent Supreme Court decisions have divided over precisely these issues, with the faction favoring a strict construction losing about as often as it wins. ${ }^{45}$ Even when the strict constructionists win, however, Congress sometimes reverses the result by statute. ${ }^{46}$ Thus, the steady encroachment of the

44. For recent and uncharacteristic defeats suffered by the government in white-collar prosecutions (all in the Second Circuit), see United States v. Chestman, 947 F.2d 551 (2d Cir. 1991) (en banc), petition for cert. filed, 60 U.S.L.W. 3500 (U.S. Jan. 1, 1992) (No. 91-1(185); United States v. Mulheren, 938 F.2d 364 (2d Cir. 1991); United States v. Regan, 937 F.2d 823 (2d Cir. 1991), modified, 946 F.2d 188 (2d Cir. 1991), petition for cert. filed sub nom. Zarzecki v. United States, 60 U.S.L.W. 3553 (U.S. Jan. 30, 1992) (No. 91 1233); United States v. GAF Corp., 928 F.2d 1253 (2d Cir. 1991).

45. The strict constructionists have recently won in McCormick v. United States, $111 \mathrm{~S}$. Ct. 1807 (1991), and in McNally v. United States, 483 U.S. 350 (1937), but they lost in Moskal v. United States, 111 S. Ct. 461 (1990). Justice Scalia's dissenting opinion in Moskal is an eloquent reaffirmation of what he terms the "Rule of Lenity - that venerable principle that "tefore a man can be punished as a criminal ... his case must be plainly and unmistakably within the provisions of some statute."' $111 \mathrm{~S}$. Ct. at 477 (Scalia, J., dissenting) (quoting United States v. Gradwell, 243 U.S. 476, 485 (1917)).

46. See, e.g., 18 U.S.C. $\S 1346$ (1988). See also Maus, supra note 14. 
criminal law upon fiduciary duties and ethical standards may be the most important and irreversible development in the substantive criminal law of this era. Can it be halted? Over the short run, I am pessimistic. De Tocqueville's observation that in America all important social and political questions ultimately become questions of law $^{47}$ needs to be extended one step further: in America, important social and political issues sooner or later unfortunately generate issues of criminal law.

47. See AleXIS DE TOCQUEVILLE, DeMOCRACY IN AMERICA 270 (Jacob P. Mayer ed., 1969) ("There is hardly a political question in the United States which does not sooner or later turn into a judicial one."). 
